Southern Methodist University

SMU Scholar

English Faculty Publications

English

Spring 2014

\title{
Seeing the Rebel: Or, How to Do Things with Dictionaries in Nineteenth-Century America
}

Tim Cassedy

Southern Methodist University, tcassedy@smu.edu

Follow this and additional works at: https://scholar.smu.edu/hum_sci_english_research

Part of the American Literature Commons, American Material Culture Commons, Cultural History Commons, Literature in English, North America Commons, and the Reading and Language Commons

\section{Recommended Citation}

Cassedy, Tim, "Seeing the Rebel: Or, How to Do Things with Dictionaries in Nineteenth-Century America" (2014). English Faculty Publications. 1.

https://scholar.smu.edu/hum_sci_english_research/1

This document is brought to you for free and open access by the English at SMU Scholar. It has been accepted for inclusion in English Faculty Publications by an authorized administrator of SMU Scholar. For more information, please visit http://digitalrepository.smu.edu. 
PLEASURE READING

Seeing the Rebel: Or, How to Do

Things with Dictionaries in

Nineteenth-Century America

\section{Tim Cassedy}

Southern Methodist University

I spend a lot of time with texts that are pretty sure of what they have to say. For example, this one-an 1816 essay about language by Timothy Dwight, the president of Yale:

The English language abounds in words, expressive of the rights, privileges, and duties, of freemen. This fact is a complete proof, independently of all history, that they [the English] have been much occupied in enjoying, and maintaining, these rights and privileges; and in performing these duties: in other words, that they have been a nation of freemen. ${ }^{1}$

I find this kind of utter certitude revealing, especially when I can't quite relate to it: I'm dubious about Dwight's claim that there is an "abundance" of words about freedom in English-and even if there is, that prevalence does not seem to me like "complete proof" of the essential liberality of English national history. Still, the history of ideas is often the history of superseded obviousnesses, and Dwight's perception of what the English language verifies about the English people is useful evidence for the argument I'm making in my book about language and identity at the beginning of the nineteenth century.

Arguments are good. So is evidence. But the more time I spend with overt, expository texts like Dwight's, the more I appreciate texts and textual artifacts that resist exposition. I came across Dwight's essay

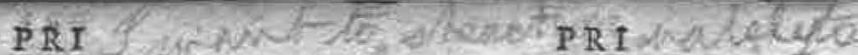

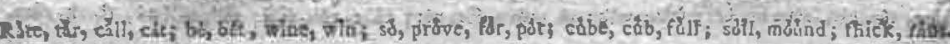

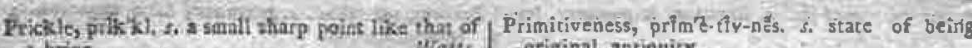
2 uriec Prictions

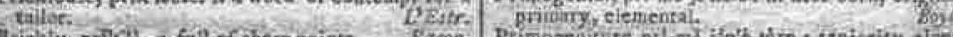
Prickiy, prika

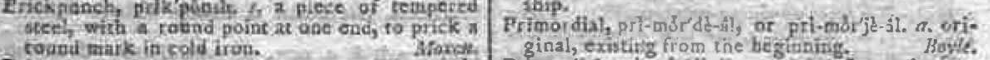

Figure 1. Handwritten marginalia in a copy of Thomas Browne's Union Dictionary (London, 1800) at the American Philosophical Society (call number VGN 423 B81U). All images are courtesy of the American Philosophical Society. This inscription reads: "I want to speack PRlvately to you."

when I was at the American Philosophical Society in Philadelphia a few years ago, reading around in early nineteenth-century philology, and I knew immediately what to do with it. But it was a different discovery at the APS, one that I did not know what to do with, that gave me a greater and more revealing pleasure, even if it is not a pleasure that I know how to make evidentiary use of. It was a copy of Thomas Browne's Union Dictionary, printed in London in 1800, in which some unknown nineteenth-century child with a pencil had apparently amused herself by making words and sentences out of the printed "catch letters" on about a hundred of the book's five hundred pages. As I turned the pages of this dictionary, puzzling out the haphazard handwriting, I felt that I was reading an unusually frank, if oddly coauthored, record of a nineteenth-century child's subjective world: promiscuous fragments of the child's heard or read environment, refracted through her imagination and her imperfect literacy, and then through the chance deletions of over-trimmed pages and fading pencil marks. Although it's not possible to know the identity of the child who penciled these words in the dictionary's margins (the book's movements between being printed in 1800 and being donated to the APS in 1991 are unknown), it is clear that the annotations date from the nineteenth century, as they had evidently already been made when the book's pages were trimmed and put into the current, decidedly nineteenth-century binding. To the extent that I was able to decipher the inscriptions, here they are. They have never been printed before: 
she did SCAre you

you have got SCAches

DELia

FIDdle sticks [and?] a FIG

FILl the Jugs with FINe rum

FIR [illegible]

the water FLOws down

GULlup it do[wn?]

HE did not like it

HIStory

INFinite

PIN your [illegible]

your in the PIT at last

POP goes the cork

pigs PORk

PORe the water out

POSsitiveliye I did

clean the POTs

do not POUt so

PRA $y$ do

I want to speack PRIvately to you

you PULled me down do not

PUNish me

the pussy PURs

QUIs me not

RAIse

he is very $\mathbf{R A V i n o u s}$

see the $\mathbf{R E B}$ ble

$\mathbf{R E M}$ member me

REPentory

REVerent old man

[illegible] REWard you

RIG the ship

Row the [illegible]

this RUM $i s$ [illegible]

SABbath

SACred

SALly come here

SALly I say come here

SARah is rich it is $\mathbf{S A T} u d a y$ you [illegible] SCHool [illegible]

\section{SCOold}

SCOld at a great rate

SCRach

[illegible] is a SEAman

get the $\mathbf{S E}$-D out at the gardin

Moona is very SENseble

see my new SERvant she must

SET down

you must SHAre you [trimmed off]

SHE is very $\mathbf{S H I}$ indeed

SHO $w$ me that doll

SIDney is a very [trimmed off]

you Backslideing SINner

SLIde with me

shut the SKIlite-....SLAve

I say

wake up you SLOth Black you shame SLUt

you are very SMArt inde[ed?]. O wall SMOther

I will SNAch that away if you do not give it to me

\section{do not SOB so}

SOI iman I [illegible]

sOLloman give me SOMe bread

SOPha

I am very SORry indeed

poor SOUl how I pitty you

Serpents VOMit poison

to win the WIN the prise is you will be WIS $e$

WOO to you

do do not WRIng your hands so

XYS $e y$

YES I guees so

that YOUng one is not [illegible]

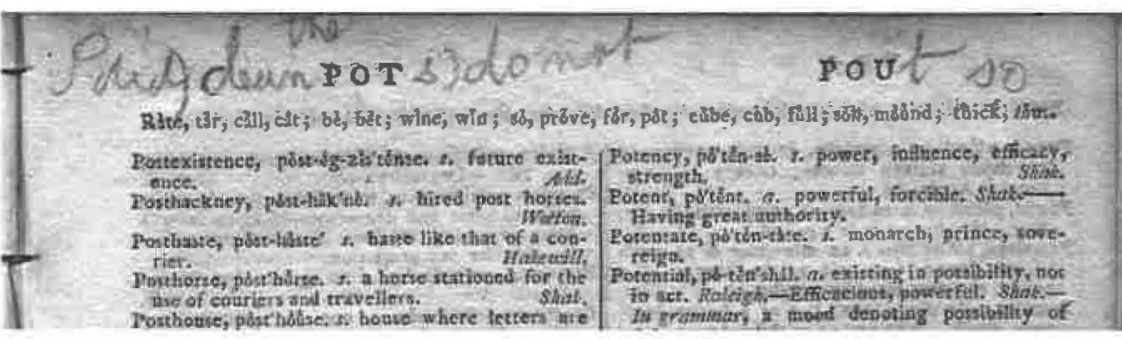

Figure 2,

To me, this artifact is the scarlet letter in the attic of Hawthorne's custom-house, brimming vividly with meanings that are not fully knowable. In some ways it is the opposite of Timothy Dwight: opaque and fragmentary, its meaning elusive and uncertain, working not in parallel with my interpretive training but somehow askew or orthogonal to it. I can't explicate this text the way I can explicate Dwight. Yet that opacity is precisely the source of the liberating pleasure I took in this object. It seemed to authorize (indeed, require) speculation and imagination and play, freeing me from a utilitarian relationship to archival research as the gathering of evidence. Years later, I like to pull up the images I took of the artifact, arranging and rearranging the inscriptions into narratives and characters in my mind: Moona is the SENseble one; Sally and Sidney are the ones who POPped the cork on a jug of FINe rum and GULluped down its contents. The text is generative and open-ended, an invitation to make my own meaning. I can allow it to mean different things because it is too sketchy, incomplete, and illegible to allow any certainties about what it "really" means.

In this respect, I have something in common with the handwritten text's nineteenth-century creator, who also made meaning out of textual fragments ensconced in institutional trappings. If a dictionary seems like an unlikely venue for a nineteenth-century child's textual creativity, it bears remembering how many non-lexicographical purposes dictionaries have always served: as doorstops, booster seats, classroom projectiles. They were also simply available; if you owned only two books in nineteenth-century America, they might well have been a dictionary and a Bible. ${ }^{2}$ And for all their stern authority, nineteenth-century dictionaries seem to have invited their own supplementation: inside nineteenthcentury dictionaries I have found handwritten Greek and Hebrew alphabets, family genealogies, drawings, flowers, and four-leaf clovers. 


\section{SI}

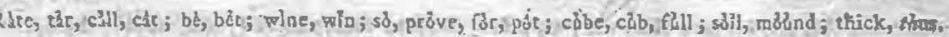

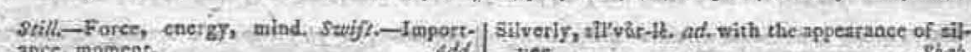

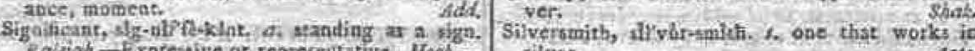

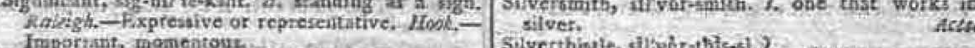

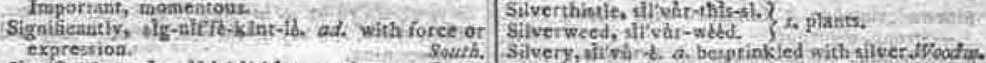

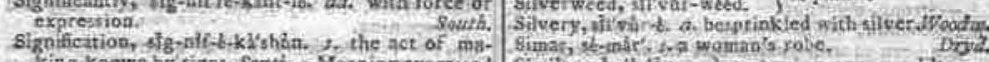

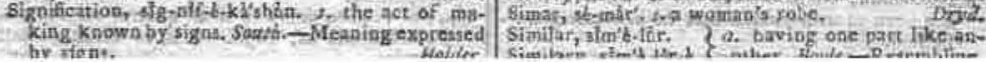

Figure 3 .

If we tend to think of dictionaries as boring and somewhat unfriendly books that dictate rules and don't care about a child's individuality, we can easily miss the significance of nineteenth-century dictionaries as sentimental sites of imaginative and material expression in which children wrote their names, circled words they knew, drew pictures, and tucked things away. The marginalia in this artifact, therefore, exemplifies the interactive and even collaborative nature of the dictionary in the nineteenth century, as a potential repository for the efforts of your creative self and the fragments of your material world. Dictionaries had a place for you, the way they had a place for every word. To be sure, a dictionary did not offer the same expressive possibilities as a blank piece of paper. The handwritten countertext to this dictionary's printed text, for example, is constrained by alphabetic order and the random occasion of the three-letter printed stems. However, to state the central paradox of Oulipians and bondage fetishists, constraints are also liberating: while you're busy paying attention to the constraint, your inhibited secrets sneak out the side door and hit the town. I think this may be the least self-conscious nineteenth-century document I have ever encountered.

I say this not because it is marginalia-which, like most other writing, has formal conventions, a history, and real and imagined audiences ${ }^{3}$ but because it seems to be an exercise in what would later be called free association. More specifically, the child who created it stumbled into a textual activity that would become one of the basic tools for studying the unconscious mind in twentieth-century experimental psychology: the word stem completion task. Like cloud-watching or the Rorschach inkblot test, this exercise pitches arbitrary cognitive material to the human subject, who projects meaning onto that material according to what already exists in his or her own mind. For research psychologists, the point of the stem completion task is that it offers access to the un-

\section{$\mathrm{SBW}$}

SHARt

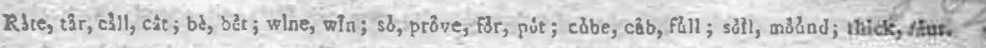
Sertee, sict-tet. s. a large long seat with a back Sewer, shbre, s. a pakage for water.

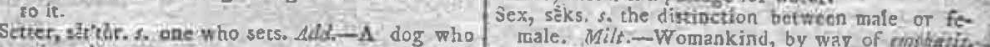
point the game.

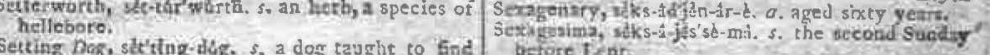

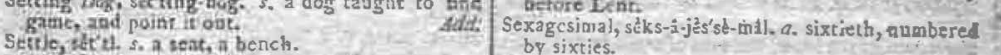

Figure 4 .

conscious in an experimentally controllable way. Dreams are another route into the unconscious, but not one that can be replicated in a laboratory setting; also, dreams are difficult to analyze in the numerical terms of statistical significance currently favored by academic social scientists. By contrast, it is easy to divide volunteers into two groups, subject the test group to some sort of manipulation, and see how their stem completions differ from the controls. For example, if you show American research subjects an image of a black male face (even subliminally, for a fraction of a second), you will see a statistically significant uptick in the number of racially stereotypical responses when you then ask them to complete the stems DU__ and STU__. ${ }^{4}$ Social psychologists are understandably interested in the cognitive and experiential factors that modulate this result.

As a literary scholar, I feel somewhat uneasy about such experiments, since I am trained to see words as elusive and unstable, their meanings always shifting and contextual. I am very uncomfortable drawing any conclusions from the mere presence or absence of a word. On the other hand, I share psychologists' core assumption that people reveal themselves in language, sometimes against their intentions or beyond their conscious understanding. I also share psychologists' interest in the non sequitur, in the sense that the point of any free association exercise is to get the analysand to say something that isn't generic. Genres are socially approved solutions to problems of representation; in my research, I often want to know what was socially approved, but I also often want to know about subjective realities that were socially unacceptable or illegible. Records of such realities are very hard to come by, because most of what gets written down, printed, preserved, archived, and cataloged is generic: it makes sense according to prevailing norms of what counts as meaningful. Hence the perpetual archival problem that it is always much easier to hear from authorized voices 


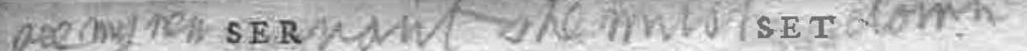

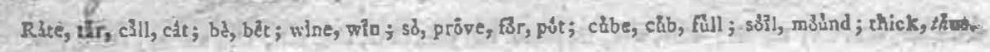

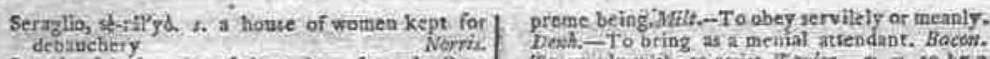

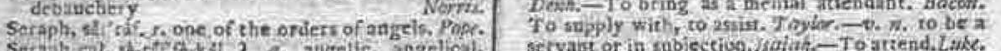

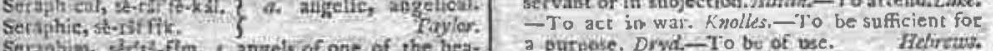

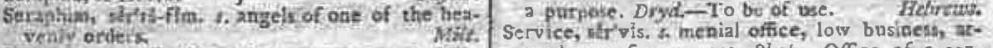

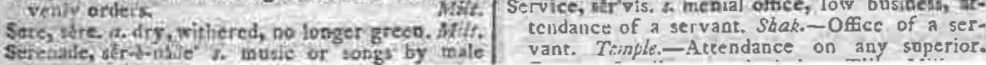
Figure 5

than unauthorized voices like the voices of children. By the time we hear from children, they tend to have been conscripted into literate adulthood and the politics of culture. The annotations in this artifact are the rare unauthorized nineteenth-century childhood utterances that have been preserved-preserved because they happen to have been blurted out into the margins of the authorized space of formal pedagogy. These partial, unsystematic, lyrical, not fully decipherable pencilings seem to me a refreshingly opaque counterpoint to the overtly comprehensive and "definitive" text that makes up the dictionary's printed content. Given my training, when a thing seems lyric and opaque, what I know how to do is do a close reading of it. Herewith, that reading:

On the one hand, the text is oriented to the material history of the bourgeois Victorian home, with its "SOPha," "doll," and "gardin." On the other hand, the text also acknowledges a wide, wide world beyond the walls of the house, an "INFinite" world extended temporally ("HIStory") as well as geographically: you could "RIG the ship," at least imaginatively, and sail off into it. I think of the text's creator as a girl-partly because the text contains more feminine than masculine names and pronouns, and partly because of that doll. On the other hand, although dolls were gendered feminine in nineteenth-century childhood, boys played with them too, ${ }^{5}$ and it may be that I think of the writer as a girl because it simply seems more interesting to me that way. The writer ("SALly"?) engages the feminized domestic domain but also thinks across the gendered boundaries of separate-sphere ideology, envisioning the near as well as the far, animals domestic ("the pussy PURs") as well as exotic ("serpents VOMit poison"), the labor of the household ("clean the POTs") as well as the labor of industrial manufacturing ("a BAR of iron is heavy").

The giving, obeying, and disobeying of mandates is at the thematic

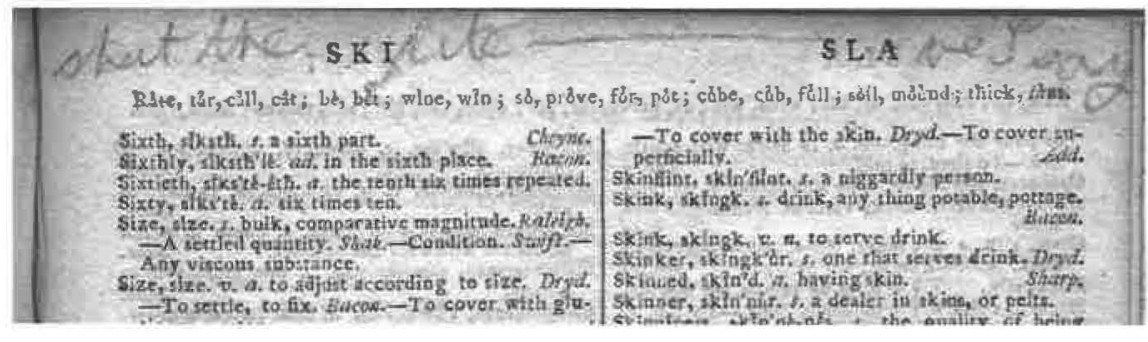
Figure 6.

center of the text. Fully half of the entries are in the imperative mood: "SALly come here," a voice in the text says, then reiterates and escalates that command: "SALly I say come here." Domestic housework defines one area of commanded behavior: "PORe the water out," "clean the POTs," "get the SEeD out at the gardin," and so on. But many other orders implicate not housework but the self, the body, and the protocols of selfcare: "do not POUt so," "do not SOB so," "do not WRIng your hands so." This is a Foucauldian world of power, accusation, and bodily surveillance, with the threat of discipline permanently hanging over it ("do not PUNish me"). The text represents conflicts and transgressions encompassing the first-world problems of bourgeois childhood, with its contradictory impulses toward materialism and altruism-as in "SHOw me that doll," "I will SNAch that away if you do not give it to me," and "you must SHAre"- as well as more elemental concerns about hunger and safety and the integrity of the body: "give me SOMe bread," "he is very RAVinous," "SCRach," "she did SCAre you." The contemptuous address to "you Backslideing SINner," the allusion not just to scolding but "SCOld[ing] at a great rate," and the ominous request "to speack PRIvately to you" suggest an atmosphere in which one might become rather practiced at deploying protestations of innocence or "REPentory" confessions of guilt ("I am very SORry indeed"). Likewise, "POSsitiveliye I did" seems like a defensive answer to an unspecified but evidently accusatory question.

So the irruption of full-fledged master-slave relations into these exercises of domestic power is at once a jarring discontinuity and a potent variation on the major theme. Slavery appears three times in the text, in increasingly stark and cruel terms:

(1) see my new SERvant she must SET down

(2) shut the SKIlite —_ SLAve I say

(3) wake up you SLOth Black you shame SLUt 


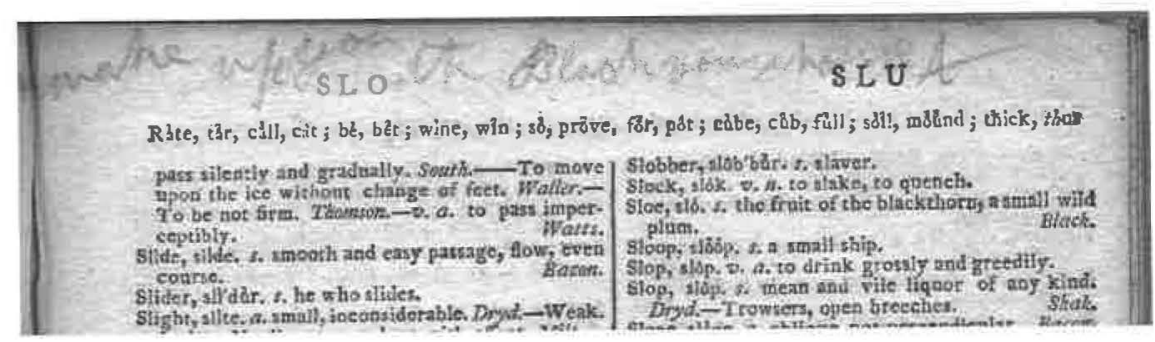

Figure 7.

This discursive appearance of slavery begins in a comparatively tentative form, with a directive issued not to the enslaved person but to someone else ("see my new SERvant"). The second imperative is more absolute: it is a command not about the subordinate but to her, and it eliminates the sliver of third-person grammatical agency available in the first, as "she must do X" yields to "do X." The potentially contractual "SERvant" of the first command has also become a definitively chattel "SLAve." The third statement most robustly outlines the conceptual scope of American race slavery, claiming supervisory authority not just over the slave's labor (as in the command to "shut the SKIlite") but over her consciousness ("wake up"), addressing the slave as racial other ("Black"), and positioning that other as a moral inferior ("sloth," "shame"). Furthermore, the interpellation of the enslaved addressee as a "shame[ful] SLUt" gestures toward the sexual violence to which female slaves were subjected and for which they were also blamed, an issue elaborately thematized in Harriet Jacobs's Incidents in the Life of a Slave Girl (1861) as well as other literary treatments of slavery. Although the word "slut" could imply merely physical messiness in nineteenth-century English, it also carried a moral significance that included - and by the end of the century would narrow into-the more specifically sexual charge with which we are more familiar. (Slut is defined on the dictionary's following page as "a dirty woman," with sluttish defined in paramoralistic terms as "nasty, not nice, not cleanly, dirty.")

It seems clear that the child for whom these phrases came to mind when contemplating the stems SER, SET, SKI, SLA, SLO, and SLU was familiar with some of the major dimensions of American slavery. But slavery is not the subject of either critique or defense here: it is simply present. When I show this text to students, the routine appearance of slavery alongside mundane inscriptions like "it is SATuday" makes

\section{R E A} REB

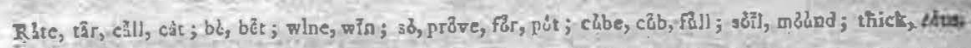

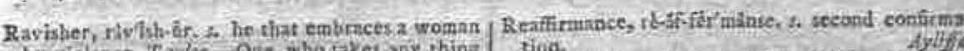
by yiolence. To, hat. - One who takes any thing tiod.

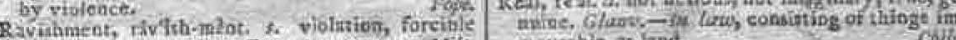

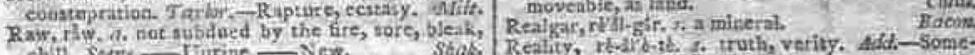

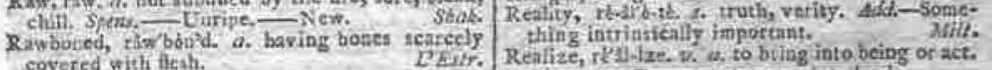
Figure 8

them uncomfortable: they want to see slavery clearly marked as distinct and extraordinary and obviously different from other forms of power. This text doesn't do that. It evokes slavery among a variety of other asymmetrical power relationships backed by the threat of violence. It registers an unfair world, which might otherwise be called "childhood," in which people are routinely hungry, scared, hurt, surveilled, and punished. Part of what the text suggests is how one person might have made sense of slavery as an institution at one extreme of, but not discontinuous with, normal human relations. That person might have been a southerner or a northerner, white or black, a slaveholder or a slave. Perhaps it was a white child in a slaveholding family, echoing phrases she heard her parents use in addressing their slaves, or words she herself used. Perhaps it was a child without firsthand experience of slavery who gained access to slavery's conceptual vocabulary through literature and political discourse. Or perhaps the writer was herself a slave-a child or an adult, female or male-articulating the discursive contours of her own enslavement. After all, slaves occasionally learned to read and write using the discarded or hand-me-down texts of white pedagogy, as this dictionary could have been. ${ }^{6}$

I can't see a way to decide among these alternatives. But all of them raise intriguing interpretive possibilities about the text's succinct directive to "see the REBble." Who is the rebel? This sentence might trace a northern child's awareness of the American Civil War, a white southern child's vigilance against the threat of slave rebellion, or an enslaved person's familiarity with a slave rebel such as Nat Turner. It might rehearse a line from an 1803 poem celebrating the suppression of an Irish insurrection ("See! the Rebel horde disperses") or an eighteenth-century hymn about the prodigal son ("Now see the Rebel raise his eyes"). ${ }^{7}$ The dictionary itself pejoratively defines a rebel as "one who opposes lawful authority." Yet that official line doesn't fully account for a text that tests 
the limits of a subordinate's disempowerment, dragging its feet as it responds to an order ("SALly come here... SALly I say come here") and overtly resisting authority at least twice ("do not PUNish me," "QUIs me not"). The very act of taking pencil in hand to write back to the disciplining word is, itself, rebellious. In the end, the handwritten text is nearly as fragmentary and partial as the word stems it's built out of, and maybe it's the same kind of cipher: with a text as fragmentary as this, we all see what we want to see.

I want to see the rebel-the readerly rebellion against reading the book as it's meant to be read, or even the readerly rebellion against reading the book at all, as opposed to writing in it, drawing pictures in it, storing objects in it. I don't believe in the value of "reading" per se. I believe in the value - the historiographical and moral value - of active engagement with language, but that engagement frequently takes forms other than reading. I like to see readers taking what they're given and doing their own thing with it, the way the annotations in this book coopt official print and turn it to another purpose. Even the most authoritative books do not get to decide how they are used, but are more or less easily drafted into practices other than what they were designed for. This child refused to go in the direction the dictionary wanted to take her, which was toward definition, certitude, and alphabetical order. She went somewhere else. I like this, because it reminds me that I have that same right of resistance to use texts in a way that doesn't lead me toward definition and certitude. Texts are about communication, and one thing I can do is listen to what they have to say and try to arrive at a clear understanding of what that is. But certainty forecloses possibilities, and texts are also about ambiguity and the unknowable. This dictionary's rebellious reader-writer reminds me of what is easily forgotten along the disciplinary straight-and-narrow: that as much as texts are for drawing conclusions and making arguments, they are also for hazarding guesses, telling stories, peering into possibilities, playing with what might be.

\section{Notes}

1. Timothy Dwight, "Observations on Language," Memoirs of the Connecticut Academy of Arts and Sciences, vol. 1, part 4 (New Haven, 1816), [366, misnumbered 126]

. Willia J. Gilm par 4 (New Han, 1816), (365, mith Life in Rural New. Gilmore, Reading Becomes a Necessity of Life: Material and Cultural 341,358 .

3. Heather J. Jackson, Marginalia: Readers Writing in Books (New Haven, CT: Yale Uniersity Press, 2001).

4. Threat," Personality and Social Psychology Bulletin 24, no. 11 (1998): 1139-52. The researchers considered racially stereotypical responses to be $d u m b$ and stupid. Participants might otherwise have completed the stems as dust, stuff, etc.

5. Miriam Formanek-Brunell, Made to Play House: Dolls and the Commercialization of American Girlhood, 1830-1930 (New Haven, CT: Yale University Press, 1993).

6. Janet Duitsman Cornelius, "When I Can Read My Title Clear": Literacy, Slavery, and Religion in the Antebellum South (Columbia: University of South Carolina Press, 1991)

7. "Rebelion Defeated," Genileman's Magazine (London), August 1803, 762; "The Prodigal Son," The Hartford Selection of Hymns (Hartford, 1799), 200. 